\title{
Isolation of a lethal virus from the endangered tiger salamander Ambystoma tigrinum stebbinsi
}

\author{
James K. Jancovich ${ }^{1}$, Elizabeth W. Davidson ${ }^{1, *}$, J. Frank Morado $^{2}$, \\ Bertram L. Jacobs ${ }^{3}$, James P. Collins ${ }^{1}$ \\ ${ }^{1}$ Department of Biology, Arizona State University, Tempe, Arizona 85287-1501, USA \\ ${ }^{2}$ National Oceanographic and Atmospheric Administration, National Marine Fisheries Service, 7600 Sand Point Way N.E., \\ Seattle, Washington 98115-0070, USA \\ ${ }^{3}$ Department of Microbiology and Molecular and Cellular Biology Program, Arizona State University, Tempe,
} Arizona 85287-1144, USA

\begin{abstract}
The Sonora tiger salamander Ambystoma tigrinum stebbinsi Lowe is a genetically distinct race restricted to about 30 small ponds in the San Rafael Valley in southern Arizona, USA, which was added recently to the USA Federal List of Endangered Species. Populations of these salamanders periodically experience decimating epizootics. Virus was isolated from diseased salamanders using fish cell cultures, injected into healthy laboratory-reared salamanders, and then reisolated in cell culture. Electron microscopy of thin sections from dying salamanders revealed abundant enveloped and nonenveloped icosahedral virus particles approximately 160 to $180 \mathrm{~nm}$ in diameter in the cytoplasm of skin and liver cells and free in the intercellular spaces. This virus, believed to be an iridovirus based on viral morphology and host pathology, was demonstrated to be the primary pathogen in these epizootics, and is the first lethal epizootic virus reported from salamanders. We have named the virus Ambystoma tigrinum Virus (ATV). Hemolytic bacteria were isolated from sick individuals, but we were unable to induce the disease by exposing salamanders to isolated bacteria at concentrations up to $10^{8} \mathrm{ml}^{-1}$
\end{abstract}

KEY WORDS: Salamander $\cdot$ Ambystoma tigrinum stebbinsi - Virus · Iridovirus · Amphibian decline

\section{INTRODUCTION}

The Sonora tiger salamander Ambystoma tigrinum stebbinsi Lowe is a genetically distinct race restricted to about 30 ponds in the San Rafael Valley (SRV) in Cochise and Santa Cruz Counties, southern Arizona, USA (Jones et al. 1995). This salamander was recently added to the USA Federal List of Endangered Species (Department of the Interior 1997). These salamanders and other Arizona populations of A. tigrinum periodically undergo decimating epizootics that were first observed in 1985 (Collins et al. 1988). These epizootics were previously ascribed to bacterial infections, such as Aeromonas hydrophila, the putative agent of 'redleg' disease in frogs; however, the causative agent of these epizootics was never determined.

•Addressee for correspondence. E-mail: e.davidson@asu.edu
In December 1995, populations of Ambystoma tigrinum stebbinsi began to show similar disease symptoms as had been reported previously (Pfenning et al. 1991, Collins pers. comm.). A virus was isolated from diseased A. tigrinum stebbinsi from the San Rafael Valley, and we have shown this virus to be the primary pathogen in these epizootics by satisfying Koch's postulates. This represents the first evidence for a lethal, highly infectious viral disease in a salamander, adding an important variable to those that must be understood before we can explain the decline, or even extinctions of amphibian populations.

\section{METHODS}

Field work. The SRV, located in southern Arizona extending into Sonora, Mexico, is a Plains grasslandMadrean evergreen woodland habitat (Brown 1982). 
Tiger salamanders are restricted to small ponds that are used to provide cattle with water. From December 1995 to March 1996 both apparently healthy and diseased larval salamanders were removed from tanks by seining. The salamanders were transported back to the laboratory, where they were immediately processed for microscopy and bacteriology or placed in aquaria and examined for disease symptoms.

Laboratory transmission. Disease transmission was attempted in the laboratory by feeding tissues from a sick individual to a healthy individual and by placing healthy larval, neotenic, and metamorphosed salamanders in water that had previously held sick salamanders. Captured or laboratory-reared Ambystoma tigrinum stebbinsi and A. tigninum nebulosum salamanders were fed tissues from 2 neotenic salamanders captured in the field, from 3 experimentally infected motamorphosed salamanders, and from a salamander that had eaten a piece of a field-infected larval salamander's body wall. All individuals were placed in 20 gallon (75 l) aquaria in the laboratory $\left(25^{\circ} \mathrm{C}\right)$ to observe disease progress before euthanasia. Healthy individuals were then introduced into the aquaria which had held diseased animals. A total of 47 salamanders were exposed to disease by water transmission.

Specimens in all experiments were fed either Tubifex sp. worms or meal worms (Tenebrio sp.) twice a week. The water and filters in the tanks were not changed and salamanders were not disturbed during the experiments. Disease was confirmed by observation of symptoms characteristic of this disease.

Disease was transmitted in the laboratory by feeding $2 \times 3 \mathrm{~cm}$ samples of body wall and liver from Stage 4 diseased salamanders (see below) to a healthy larval Ambystoma tigrinum stebbinsi or A. tigrinum nebulosum and was passed serially through 3 additional larval or neotenic salamanders.

Water (4 l) previously holding individuals with the disease ('infectious water') was filtered through a coffee filter, a Whatman \#1 filter paper (Whatman, England), and finally through a $0.45 \mu \mathrm{m}$ Metricel $^{(\oplus}$ membrane filter (Gelman Sciences, USA). Both laboratory-bred and captured Ambystoma tigrinum stebbinsi and $A$. tigrinum nebulosum were placed in either unfiltered infectious water, filtered $(0.45 \mu \mathrm{m})$ infectious water, infectious water that was autoclaved $\left(121^{\circ} \mathrm{C} /\right.$ $20 \mathrm{~min}$ ) or fresh conditioned water

Processing specimens. Salamanders were euthanized in 1\% MS-222 (Argent Chemical Laboratories, USA) and tissues were either immediately fixed for electron or light microscopy, or frozen in $20 \%$ glycerol in $0.9 \% \mathrm{NaCl}$ at $-70^{\circ} \mathrm{C}$. Tissues were fixed for light histology in $10 \%$ formalin buffered with magnesium carbonate, embedded in paraffin, sectioned, and stained with hematoxylin and eosin. Tissues were fixed for electron microscopy in $4 \%$ paraformaldehyde and $0.25 \%$ gluteraldehyde in Sorensen's buffer pH 7.2, postfixed with $1 \%$ osmium tetroxide, dehydrated, and embedded in Spurr's resin (Electron Microscopy Sciences, USA) (Miller \& Brown 1992). Thin sections (10 to $20 \mathrm{~nm}$ ) were cut and stained with $4 \%$ uranyl acetate and $4 \%$ lead citrate before being examined with a Philips EM201 electron microscope.

Bacteriology. Tissue samples from sick and healthy larval salamanders were rinsed 3 times in sterile saline. homogenized with a Dounce homogenizer and plated on potato dextrose agar, MacConkey agar, nutrient agar and blood agar (Difco Co., USA; MicroBio, USA). Blood samples were taken from gill clippings using heparinized capillary tubes and were plated on blood agar (MicroBio, USA). Colonies were streaked for purity and frozen at $-70^{\circ} \mathrm{C}$ in nutrient broth (Difco Co.) with $20 \%$ glycerol until they could be identified. Pure cultures of hemolytic bacteria were identified using Gram's stain and A.PI Manual Test Systems (bioMerieux Vitek, Inc., USA). Larval salamanders Ambystoma tigrinum stebbinsi from laboratory colonies were exposed to concentrated broth cultures of 4 different hemolytic bacterial isolates and a combination of all 4 isolates. Briefly, hemolytic bacteria cultured for $24 \mathrm{~h}$ in $40 \mathrm{ml}$ of nutrient broth were pelleted by centrifugation at $3150 \mathrm{rpm}$ ( $1619 \times \mathrm{g}$, clinical centrifuge) for $5 \mathrm{~min}$. The bacteria were then resuspended in $10 \mathrm{ml}$ of nutrient broth and added to $4 \mathrm{l}$ of laboratory water containing salamanders. The same bacteria were added again 2 wk later. Bacterial concentrations were estimated by dilution plate counting. Five larval salamanders were used for each treatment and each treatment was repeated twice.

Cell culture. Two fish cell lines were used to isolate the virus. EPC (epithelioma papilloma cyprini) (Fijan et al. 1983) and BF2 (bluegill fry) (Wolf et al. 1966) cells were cultured in Eagle's minimum essential medium (MEM) (Sigma, USA) supplemented with 10\% fetal bovine serum (FBS) (Hyclone, USA) at $24^{\circ} \mathrm{C}$ in $75 \mathrm{~cm}^{2}$ flasks. Salamander tissues were homogenized in MEM with $2 \%$ FBS, centrifuged at $5000 \mathrm{rpm}(3015 \times$ g, Sorvall) for $15 \mathrm{~min}$ and the supernatant filtered through $0.45 \mu \mathrm{m}$ filters (Micron Separations Inc., USA). Tissue homogenates were diluted in MEM with $2 \%$ FBS. Cells were infected at $24^{\circ} \mathrm{C}$ for $1 \mathrm{~h}$ with $100 \mu \mathrm{l}$ of diluted tissue homogenates, and flasks were rocked every $10 \mathrm{~min}$ for $1 \mathrm{~h}$. After $1 \mathrm{~h}$, MEM with $10 \%$ FBS was added to the flasks and the cells were incubated at $24^{\circ} \mathrm{C}$. When the cell monolayer had been completely destroyed, virus and infected cells were harvested and stored at $-70^{\circ} \mathrm{C}$. Uninfected cells were scraped from dishes and frozen at $-70^{\circ} \mathrm{C}$ to use as control for transmission assays.

Specimen injections. Control cells and virus-containing preparations were frozen $\left(-70^{\circ} \mathrm{C}\right)$ and thawed 
$\left(25^{\circ} \mathrm{C}\right) 3$ times before challenging salamanders. Larval salamanders from laboratory stocks (Ambystoma tigrinum nebulosum $)(\mathrm{n}=12$ ) were injected intraperitoneally with either: $100 \mu \mathrm{l}$ of cell culture medium alone; uninfected cells and medium; infected cells that exhibited a cytopathic effect; or $0.45 \mu \mathrm{m}$-filtered homogenates of tissues from diseased salamanders. Specimens were placed individually into fresh water at $25^{\circ} \mathrm{C}$ and not handled again for $10 \mathrm{~d}$. Individuals showing symptoms of the disease were euthanized with MS222, and tissues were processed as described above for cell culture inoculation.

\section{RESULTS}

During the course of this study the disease was observed in 5 cattle tanks throughout the SRV. One tank, Encino Vista, had over 80 dead salamanders lining its bank. The behavior and symptoms of diseased salamanders were difficult to study in the field due to opacity of the water. Clinical signs of the disease in the laboratory developed 5 to $7 \mathrm{~d}$ after exposure at $25^{\circ} \mathrm{C}$, but required more than $21 \mathrm{~d}$ at $8^{\circ} \mathrm{C}$. Progression of the disease syndrome in the laboratory was divided into 4 stages. Stage 1 was characterized by individual small white polyps that covered less than $10 \%$ of the epidermis. During Stage 2, the polyps had spread to cover about $50 \%$ of the salamander's epidermis, and during Stage 3 hemorrhaging of the epidermis was often observed with $90 \%$ of the epidermis being covered by the polyps. In Stage 4 the salamanders generally had hemorrhaging of the epidermis as well as some of the internal organs, and they became lethargic, refused food, floated near the surface of the water, and often excreted bloody mucus from the cloaca (Fig. 1). Salamanders captured in the field did not display obvious epidermal polyps, but were covered with sloughed skin and mucus.

Transmission experiments gave insight as to the causative agent of the disease. First, all of the test individuals that were put into water previously holding a diseased salamander produced initial individual polyps within ca $7 \mathrm{~d}$, and the progression of the disease through the 4 stages was observed in all salamanders. Feeding tissues from a diseased individuals to healthy individuals also resulted in disease transmission to $100 \%$ of the salamanders. Using water in which salamanders had died as experimental inoculum, healthy salamanders were infected after being placed in water that had passed through $0.45 \mu \mathrm{m}$ filters, but the infectious ability of the water was lost after standing $2 \mathrm{wk}$ at $25^{\circ} \mathrm{C}$ or after autoclaving. None of the control specimens in any of the above experiments exhibited the disease symptoms.

Before the highly infectious nature of the disease was well understood, it was unintentionally transmitted by handling healthy salamanders used for laboratory breeding after processing diseased individuals. Of the 102 salamanders used in the breeding experiments during $1996,49 \%$ died within a few weeks of breeding.

Hemolytic bacteria, including Aeromonas, Pseudomonas, and Bacillus spp., were isolated from $71 \%$ of diseased salamanders $(n=52)$. We were unable to induce the disease symptoms by holding salamanders
Fig. 1 Ambystoma tigrinum. Larval tiger salamander removed from the San Rafael Valley in the later stages of disease. Epidermis is covered with sloughed skin and mucus

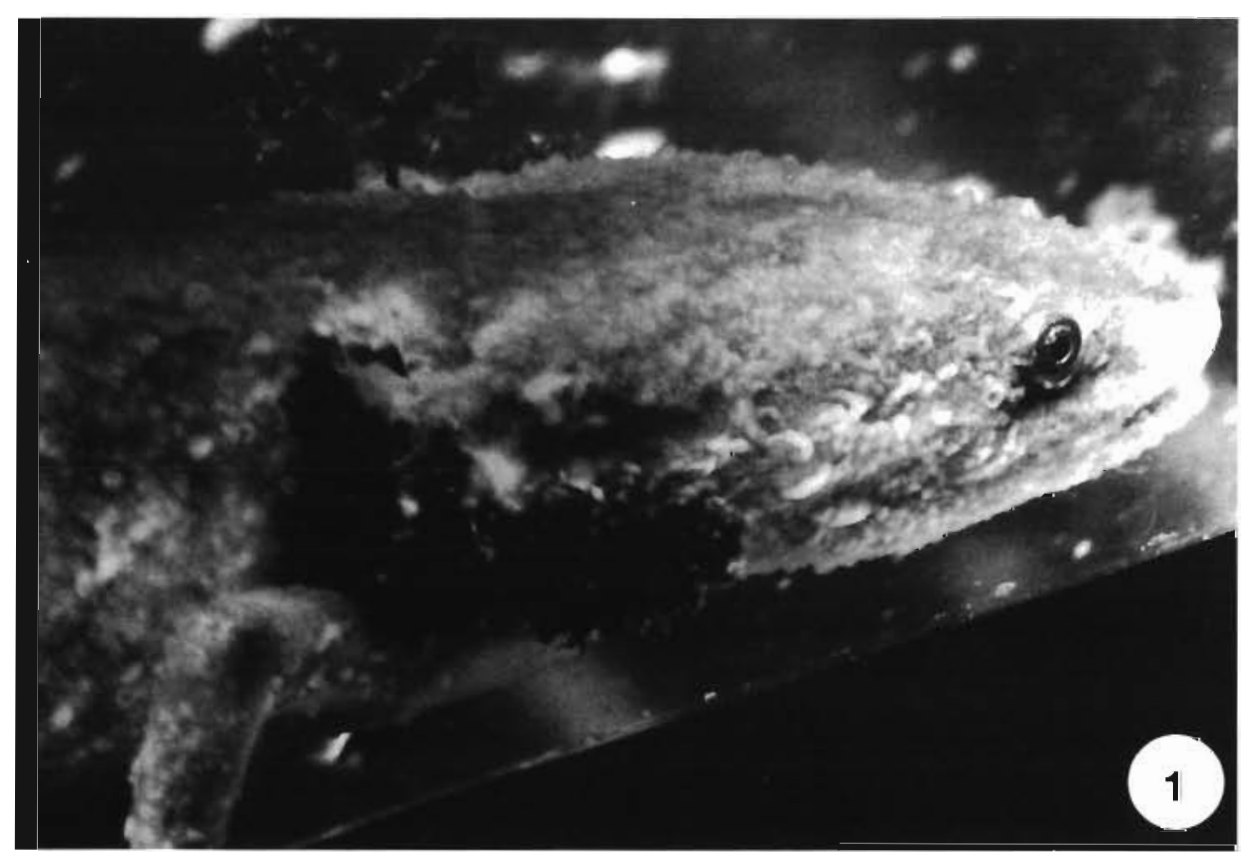




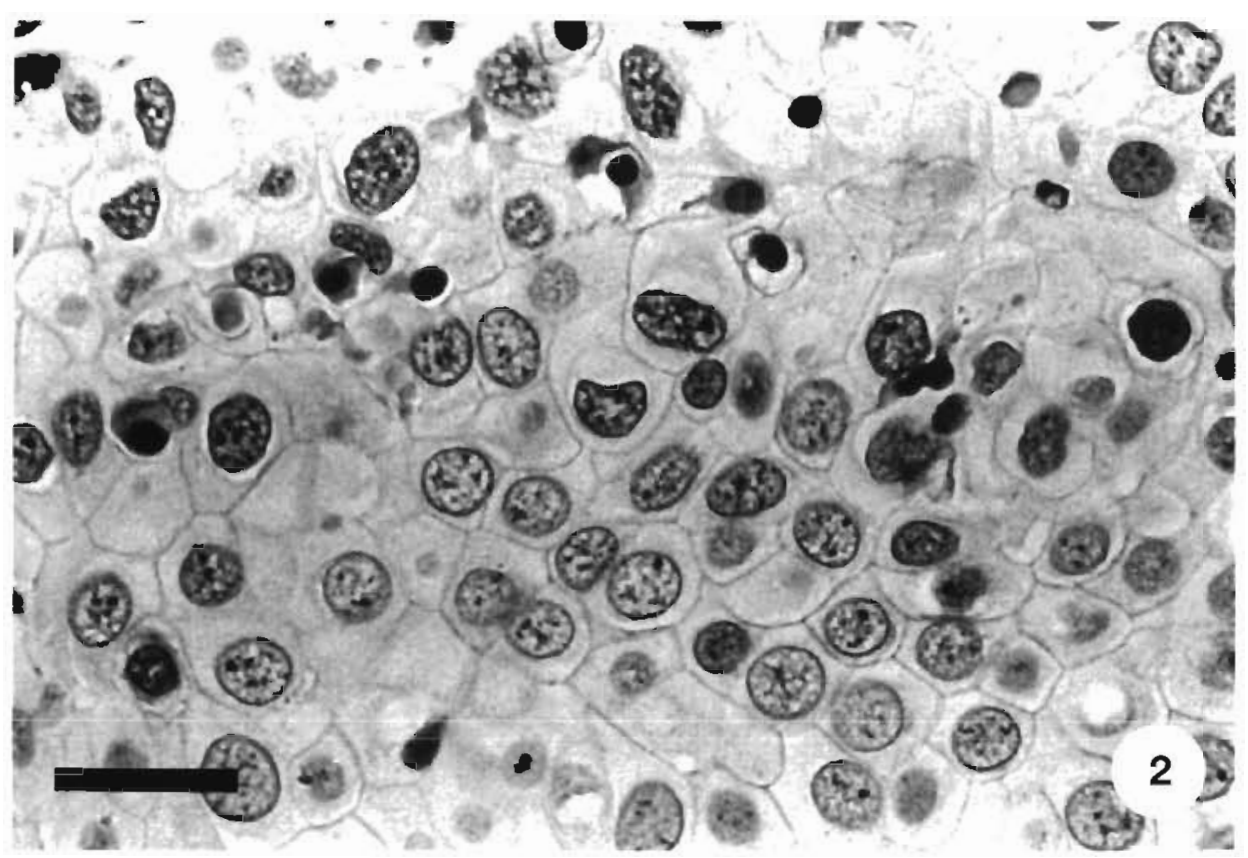

Fig. 2. Ambystoma tigrinum. Light micrograph. Epidermis of tiger salamander infected with Ambystoma tigrinum virus (ATV), stained with hemotoxylin and eosin, showing epidermal cells with enlarged nuclei, marginated chromatin, and nuclear inclusions. Scale bar $=10 \mu \mathrm{m}$ in water containing pure cultures of isolated bacteria at concentrations up to $10^{8} \mathrm{ml}^{-1}$. Sixty individuals were exposed to bacterial isolates as well as combinations of the 4 hemolytic bacterial isolates. Only 4 individuals exposed to bacteria died; however, their symptoms were not those described above. None of the untreated control specimens exhibited disease symptoms.

Light microscopy of experimentally infected larval salamanders revealed hypertrophied cells of the epidermis, gills, and liver of sick individuals displaying enlarged nuclei with marginated chromatin and nuclear inclusions suggestive of viral infections (Fig. 2). The polyps appeared to result from cellular proliferation of the outer epidermal layer. Electron microscopy of thin sections from dying Stage 4 larval salamanders revealed abundant enveloped and non-enveloped icosahedral virus particles approximately 160 to $180 \mathrm{~nm}$ in diameter in the cytoplasm of skin and liver cells and free in the intercellular spaces (Figs. 3 \& 4).

Filtered homogenates of tissue from sick individuals produced cytopathic effects in both EPC and BF2 cell cultures within $48 \mathrm{~h}$ (Fig. 5). Salamanders chal-

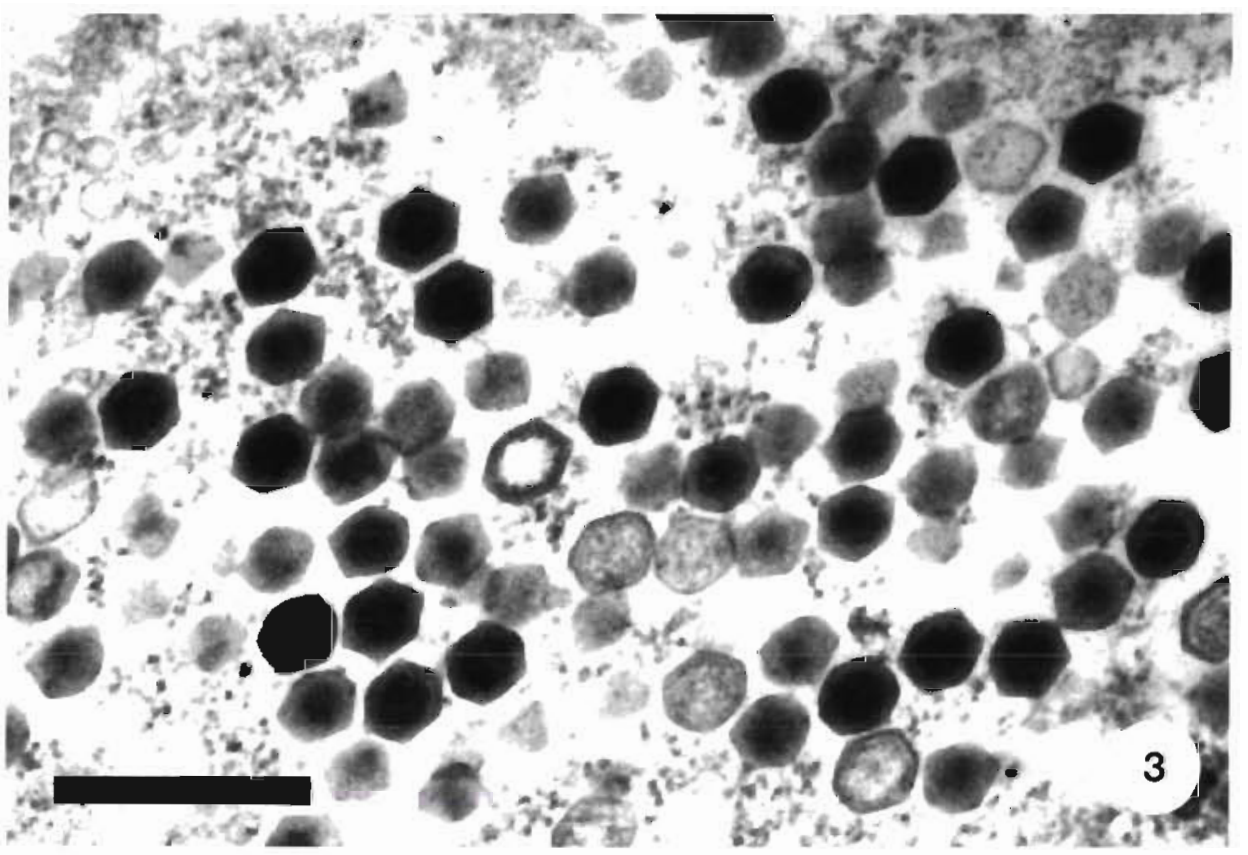

Fig. 3. Ambystoma tigrinum Electron micrograph. Epidermis of tiger salamander infected with ATV showing nonenveloped viral particles in the cytoplasm of an epidermal cell. Scale bar $=0.5 \mu \mathrm{m}$ 
Fig. 4. Ambystoma tigrinum. A single virion from the body wall showing typical icosahedral morphology and lipid bilayer envelope. Scale bar = $0.1 \mu \mathrm{m}$

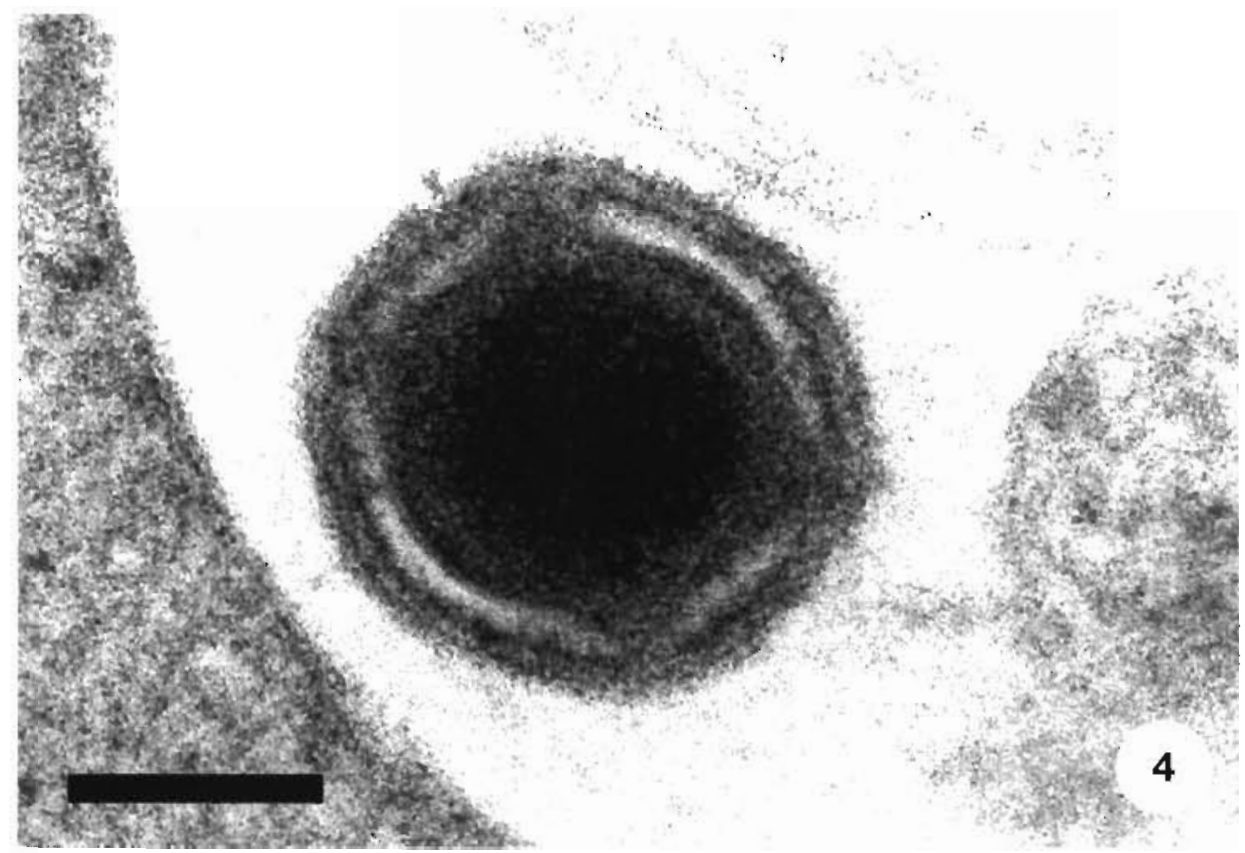

lenged with virus grown in cell cultures or with filtered homogenates of diseased salamanders exhibited the same symptoms as described above within 5 to $7 \mathrm{~d}$ of injection. Virus was reisolated from individuals infected with virus passed through cell culture, and again cytopathic effects on BF2 cells were observed within $48 \mathrm{~h}$ of infection with filtered homogenates of these individuals. Homogenates of control specimens did not produce disease symptoms in injected salamanders or a cytopathic effect on cell cultures

\section{DISCUSSION}

Initial experiments suggested that a virus was the causative agent of the disease in Ambystoma tigrinum stebbinsi, as autoclaved infectious water did not produce disease, but water filtered through $0.45 \mu \mathrm{m}$ filters did produce disease. Filtration through $0.45 \mu \mathrm{m}$ eliminates most bacteria and protozoa, but allows passage of most viral particles. Salamanders exposed in the laboratory to infectious cell culture extracts, homogenized salamander tissue, or infectious water filtered
Fig. 5. EPC cells infected with virus showing a plaque in the monolayer, $24 \mathrm{~h}$ post infection. Scale bar $=100 \mu \mathrm{m}$

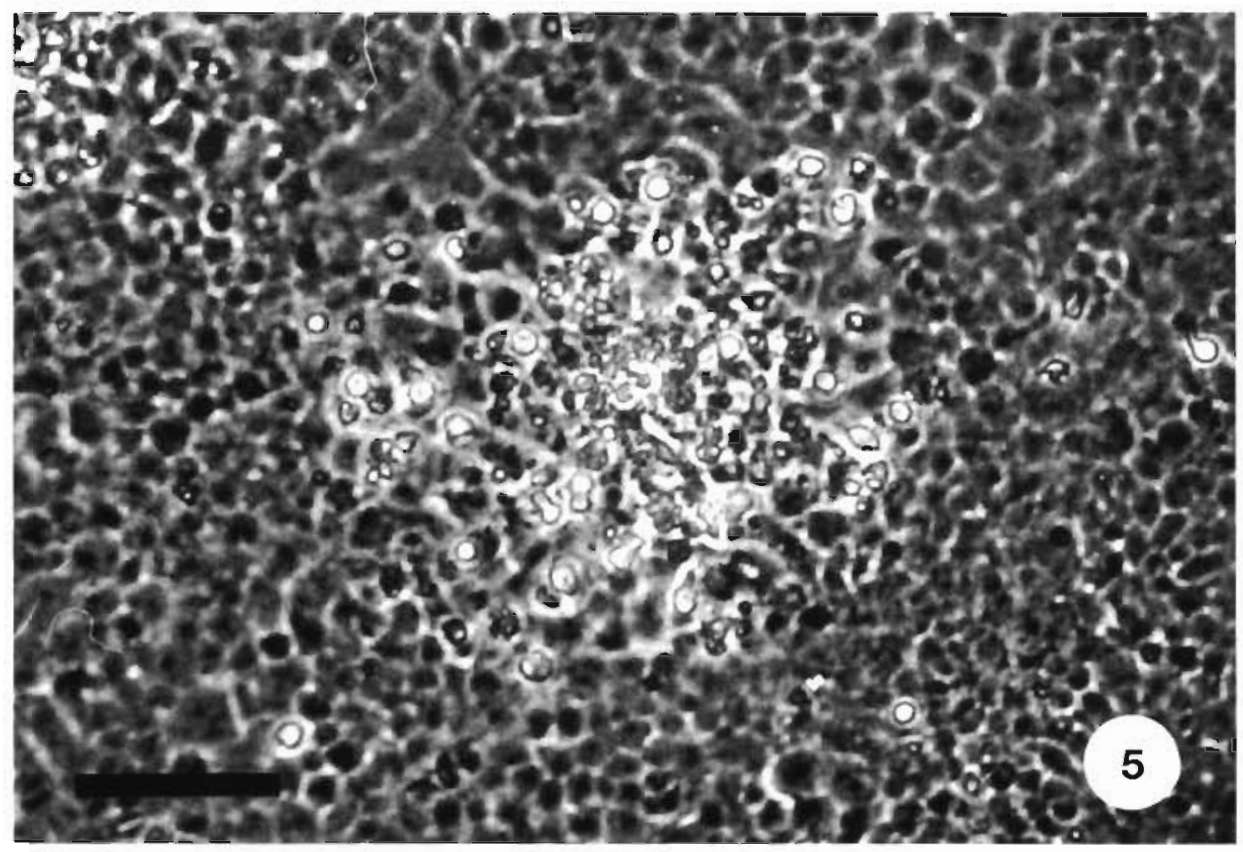


through $0.45 \mu \mathrm{m}$ filters produced the same disease symptoms as salamanders that had been infected in the field. Salamanders in the field did not display the obvious epidermal polyps, but these structures may have been lost during seining. High concentrations of hemolytic bacteria isolated from diseased individuals did not produce the same disease symptoms, or significant mortality. In addition, we did not isolate the same bacterial species from all of the diseased individuals, suggesting that bacteria were not the cause of the disease. However, we believe that bacteria may often be secondary pathogens.

We have satisfied Koch's postulates by passage of the infectious agent through cell culture and back into the host producing the same symptoms as observed in diseased salamanders in the field. This process was repeated through 3 cycles. Cytoplasmic particle development and icosahedral morphology suggest that the virus is an iridovirus, which we have named $A m b y$ stoma tigrinum Virus (ATV). Iridoviruses have been reported from fish, reptiles, frogs and insects (Anthony \& Comps 1988, Willis 1990, Wolf 1991). Cytoplasmic viruses of similar appearance were isolated from newts, but none of the isolates produced obvious disease in immature newts (Clark et al. 1969).

ATV is highly virulent. Before the virus was identified, neotenic and metamorphosed Ambystoma tigrinum stebbinsi and $A$. tigrinum nebulosum used for breeding and maintaining laboratory colonies exhibited the disease. Transmission was attributed to handling healthy individuals after handling diseased individuals. Regardless of method of exposure to ATV, salamanders that exhibited Stage 1 of the disease all progressed to death.

The decline or extinction of amphibian populations has been ascribed to human intervention, ultraviolet radiation, environmental degradation, habitat disruption, introduced predators and disease (Blaustein \& Wake 1990, Carey 1993, Corn 1994, Fisher \& Shaffer 1996). The role of epidemic disease, including viruses, in the decline of amphibian populations is unclear and has recently been the topic of considerable discussion (e.g. Alford \& Richards 1997, Hero \& Gillespie 1997 , Laurance et al. 1997). Catastrophic declines of Australian rain forest frogs have been ascribed to a highly virulent agent (Laurance et al. 1996), although this organism has not yet been isolated and identified (Laurance et al. 1997). Cunningham et al. (1996) concluded that disease of British frogs producing 'red-leg' symptoms probably resulted from primary iridovirus infections, not Aeromonas hydrophila or other bacteria as previously assumed. Hemolytic bacteria, including Aeromonas, were found in two-thirds of the salamanders we examined, suggesting bacteria may be common secondary pathogens in ATV infections as well.
Salamander die-offs in Arizona previously attributed to bacterial infections may also have been caused by ATV (Berna 1982, Collins et al. 1988, Pfenning et al. 1991).

Ambystoma tigrinum stebbinsi has been observed to recolonize the ponds in the SRV following die-offs; however, we do not know whether the salamanders recolonizing these ponds are survivors of the disease or migrants from other ponds. Transmission of ATV between ponds may be due to cattle, humans, birds, invertebrates or amphibians that move freely throughout the valley. We cannot predict the impact of ATV on the long-term survival of the $A$. tigrinum stebbinsi population in the SRV. As suggested by Laurence et al. (1996) for the disease of rainforest frogs in Australia, the high degree of virulence of ATV toward A. tigrinum suggests that this is a new disease to this host. Some amphibian iridoviruses, for example the Bohle iridovirus, have been shown to be pathogenic to fish (Moody \& Owens 1994). ATV readily multiplies in fish cell culture, suggesting that this virus may have been introduced into the SRV in fish. Alternatively, ATV may have originated from bullfrogs (Rana catesbeiana) or introduced salamanders (waterdogs, A. tigrinum spp.) commonly used as fish bait in Arizona (Collins 1981, Collins et al. 1988). We share the concern expressed by Laurence et al. $(1996,1997)$ that introduction of exotic species into the amphibian habitat may result in introduction of virulent pathogens to native species.

A molecular comparison of this virus to other amphibian and fish iridoviruses is now in progress. In addition, we are currently attempting to learn more about the host range and to find carriers of ATV. Our study is the first to provide conclusive experimental evidence for a lethal epizootic virus in salamanders, and adds weight to the suggestion that there is an urgent need to examine the role of infectious diseases, particularly viruses, in amphibian population dynamics.

Acknowledgements. We thank Dr R. P. Hedrick of the University of California, Davis, for providing us with the cell lines used in this study, and Dr R. Roberson for the light microscopy photographs.

\section{LITERATURE CITED}

Alford RA, Richards SJ (1997) Lack of evidence for epidemic disease as an agent in the catastrophic decline of Australian rain forest frogs. Conserv Biol 11:1026-1029

Anthony DW, Comps M (1991) Iridoviridae. In: Adams JR, Bonami JR (eds) Atlas of invertebrate viruses. CRC Press, Florida, p 55-86

Berna HJ (1982) Ecology and life history of the tiger salamander Ambystoma tigrinum nebulosum Hallowell on the Kaibab Plateau. MS thesis, Arizona State University, Tempe, p 1-121 
Blaustein AR, Wake DB (1990) Declining amphibian populations: a global phenomenon. TREE 5:203-204

Brown DE (1982) Biotic communities of the American Southwest-United States and Mexico, Vol 4, Desert plants. Boyce Thompson Southwest Arboretum, Superior, AZ

Carey C (1993) Hypothesis concerning the causes of the disappearance of boreal toads from the mountains of Colorado. Conserv Biol 7:355-362

Clark HF, Gray C, Fabian F, Zeigel R, Karzon DT (1969) Comparative studies of amphibian cytoplasmic virus strains isolated from the leopard frog, bullfrog, and newt. In: Mizell M (ed) Biology of amphibian tumors. SpringerVerlag, New York, p 310-326

Collins JP (1981) Distribution, habitats, and life history variation in the tiger salamander, Ambystoma tigrinum, in eastcentral and southeast Arizona. Copeia 1981(3):666-675

Collins JP, Jones TR, Berna HJ (1988) Conserving genetically distinctive populations: the case of the Huachuca Tiger Salamander (Ambystoma tigrinum stebbinsi Lowe). In: Szaso RL, Stevenson KC, Patton DR (eds) Management of amphibians, reptiles and small mammals in North Anerica. U.S. Department of Agriculture/Forestry Service General Technical Report RM-166, Rocky Mountain Forest and Range Experiment Station, Fort Collins, CO, p 45-53

Corn PS (1994) What we know and don't know about amphibian declines in the west. In: Covington WW, DeBano LF (tech coordinators) Sustainable ecological systems: implementing an ecological approach to land management. U.S. Department of Agriculture/Forestry Service General Technical Report RM-247, Rocky Mountain Forest and Range Experiment Station, Fort Collins, CO, p 59-67

Cunningham AA, Langton TES, Bennett PM, Lewin JF, Dury SEN, Gough RE, MacGregor SK (1996) Pathological and microbiological findings from incidents of unusual mortality of the common frog (Rana temporaria). Philos Trans R Soc Lond B 351:1539-1557

Department of the Interior (1997) Endangered and threatened wildife and plants; determination of endangered status for three wetland species found in southern Arizona and

Editorial responsibility: Jo-Ann Leong,

Corvallis, Oregon, USA northern Sonora, Mexico. Fish and Wildlife Service, Department of the Interior, Federal Register 62(3): $665-689$

Fijan N, Matasin Z, Petrinic Z, Valpotic I, Zwillenberg LG (1983) Some properties of the Epithelioma papulosum Cyprini (EPC) cell line from carp Cyprinus carpio. Ann Virol (Institut Pasteur) 134:207-220

Fisher RN, Shaffer HB (1996) The decline of amphibians in California's Great Central Valley. Conserv Biol 10 : $1387-1397$

Hero JM, Gillespie GR (1997) Epidemic disease and amphibian declines in Australia. Conserv Biol 11:1023-1025

Jones TR, Routman EJ, Begun DJ, Collins JP (1995) Ancestry of an isolated subspecies of salamander, Ambystoma tigrinum stebbinsi Lowe: the evolutionary significance of hybridization. Mol Phylogenet Evol 4:194-202

Laurance WF, MCDonald KR, Speare R (1996) Epidemic disease and the catastrophic decline of Australian rain forest frogs. Conserv Biol 10:406-413

Laurance WF, McDonald KR, Speare R (1997) In defense of the epidemic disease hypothesis. Conserv Biol 11 . $1030-1034$

Miller ML, Brown DT (1992) Morphogenesis of Sindbis virus in three subclones of Aedes albopictus (mosquito) cells J Virol 66:4180-4190

Moody NJG, Owens L (1994) Experimental demonstation of the pathogenicity of a frog virus, Bohle iridovirus, for a fish species, barramundi Lates calcarifer. Dis Aquat Org 18 : 95-102

Pfennig DW, Loeb MLG, Collins JP (1991) Pathogens as a factor limiting the spread of cannibalism in tiger salamanders. Oecologia 88:161-166

Willis DB (1990) Taxonomy of iridoviruses. In: Darai G (ed) Molecular biology of iridoviruses. Kluwer, Boston, p 1-12

Wolf K (1988) Fish viruses and fish viral diseases. Cornell University Press, NY

Wolf K, Gravell M, Malsberger RG (1966) Lymphocystis virus: isolation and propagation in centarchid fish cell lines. Science 151:1004-1005

Submitted: June 19, 1997; Accepted: October 6, 1997 Proofs received from author(s): December 19, 1997 